\title{
Oncofertility treatment of adult granulosa cell tumor in adolescent with risk of thromboembolic event
}

\author{
Dražan Butorac ${ }^{1}$, Ana-Meyra Potkonjak ${ }^{1}$, Meri Margreitner ${ }^{2}$, Marina Kos ${ }^{1}$, and Gorana \\ Mirošević $^{1}$ \\ ${ }^{1}$ Klinička Bolnica Sestre Milosrdnice \\ ${ }^{2}$ Health Centre Zagreb East
}

July 31,2020

\begin{abstract}
Adult granulosa cell tumor is predominant form of granulosa cell tumor, typically diagnosed after the age of 40 years. We report a case of a 16-year-old girl with an AGCT who presented with raised testosterone levels. After fertility sparing surgery, patient was commenced on combined oral contraceptives (COCs) due to the menstrual cycle irregularities. Subsequently, patient's father developed pulmonary embolism caused by venous thromboembolism. Hematologic evaluation in our patient, revealed decreased protein S levels. Nevertheless, COCs were continued for up to the six months. Since menstrual cycles irregularities reoccurred, we are starting with progesterone-only oral contraceptives at present time.
\end{abstract}

\section{Hosted file}

main text granulosa.doc available at https://authorea.com/users/347774/articles/473324oncofertility-treatment-of-adult-granulosa-cell-tumor-in-adolescent-with-risk-ofthromboembolic-event 

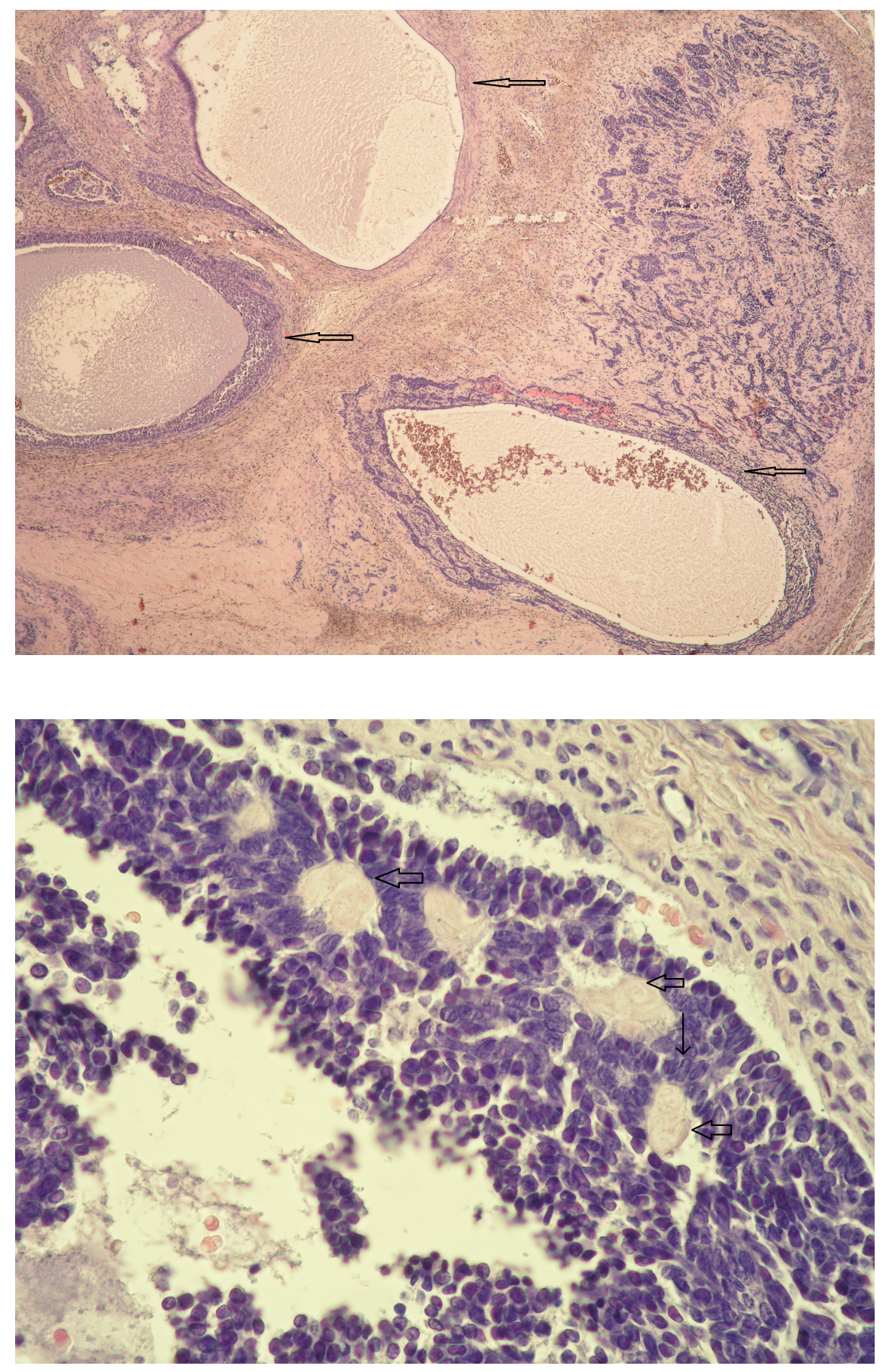